\title{
RENEWABLE ENERGY DEVELOPMENT ON TRJBAL LANDS
}

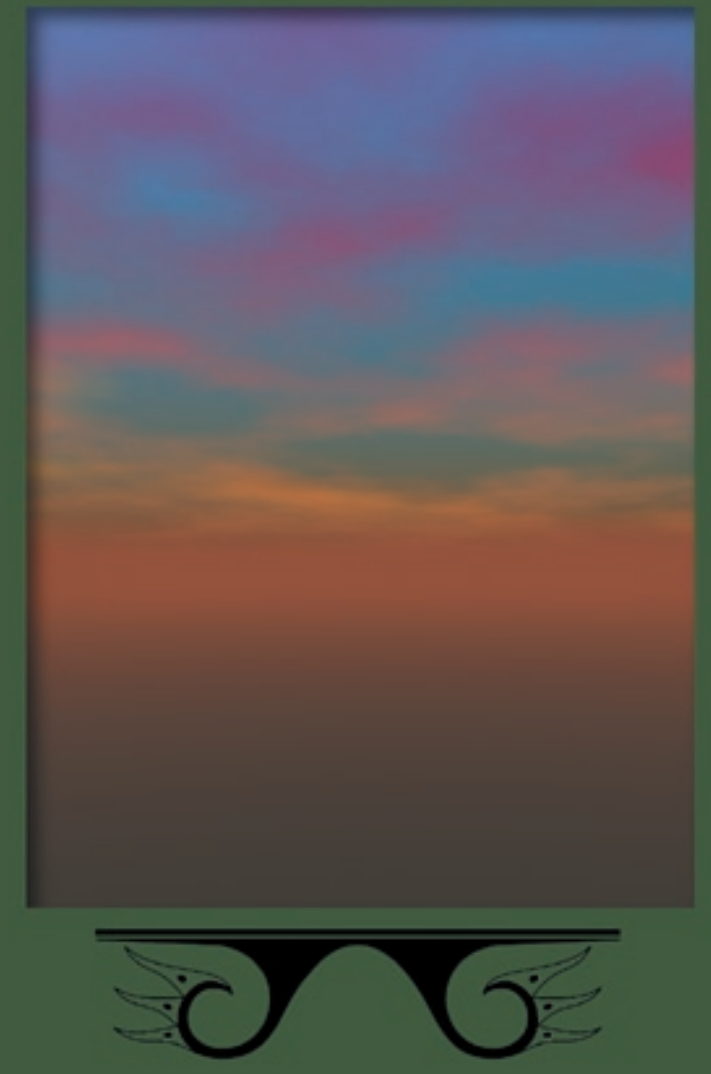




\section{Our Mission}

To offer financial and technical assistance to Tribes through government-to-government partnerships that:

1) Allow Tribal leaders to make informed decisions

2) Bring renewable energy and energy efficiency options to Indian Country

3) Enhance human capacity through education and training

4) Improve local Tribal economies and the environment

5) Make a difference in the quality of life of Native Americans. 


\section{Purpose}

The program promotes Tribal energy sufficiency, economic development, and employment on Tribal lands through the use of renewable energy and energy efficiency technologies.

The Tribal Energy Program, under the Department of Energy's (DOE's) Office of Energy Efficiency and Renewable Energy, provides financial and technical assistance to Tribes for the evaluation and development of renewable energy resources on Tribal lands. As building knowledge and skills is essential to developing, implementing, and sustaining energy efficiency and renewable energy development projects, the program also offers education and training opportunities.

\section{Policy}

The Department of Energy's American Indian and Alaska Native Tribal Government Policy sets forth principles to be followed by DOE to ensure effective implementation of governmentto-government relationships with American Indians and Alaska Native Tribal governments. Through the authorities set forth in the Energy Policy Acts and Executive Orders, DOE is seeking to support energy sufficiency on Tribal lands and support the trust responsibility set forth in DOE's American Indian and Alaska Native Tribal Government Policy.

For DOE's policy, visit www.ci.doe.gov/indianbk.pdf
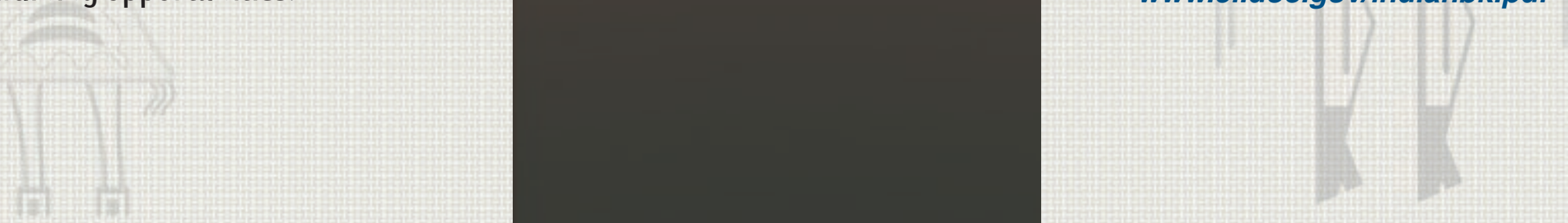


\section{U.S. Department of Energy}

\section{Energy Efficiency and Renewable Energy}

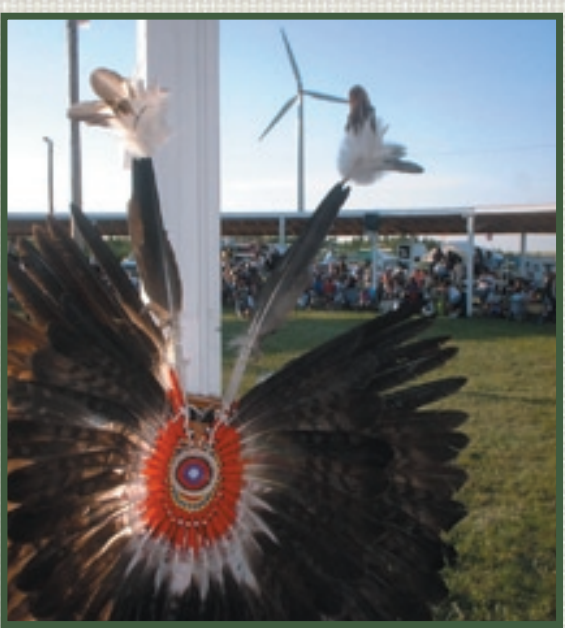

DOE has funded

91 Tribal energy projects totaling \$14.1 million from 2002 to 2007

Turbine installed at Rosebud Sioux Reservation in South Dakota

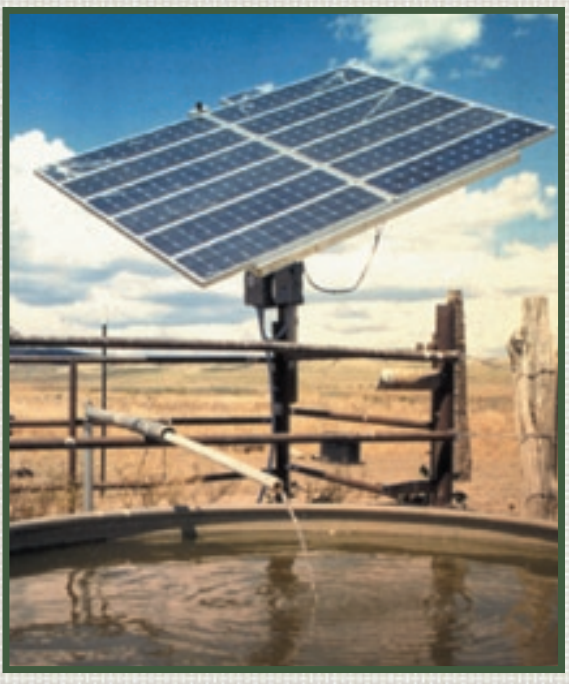

Ute Mountain Indian Reservation solar water pumping

Type of Project:

First Steps - 34

Feasibility -51
Development - 6 Smith River (2) Yurok (3) OFt. Bidwell Hoopa Valley Samish O Upper Skagit Tulalip ocolville Quinault 88 OUmatilla 8 Flathead (2) 0 Ft. Belknap Northern Cheyenne (2) 8 Eastern Shoshone Wind River O Shoshone Paiute :

O Robinson<smiles>CC1CCCC1</smiles>
Morongo Ramona $O$ Mesa Grande 8 Agua Caliente White Mtn. Jemez Viejas OCabazon White Mtn. Laguna Manzanita 0 Augustine OAk-Chin NANA Regional Corp. (3) Venetie O Ft. Yukon
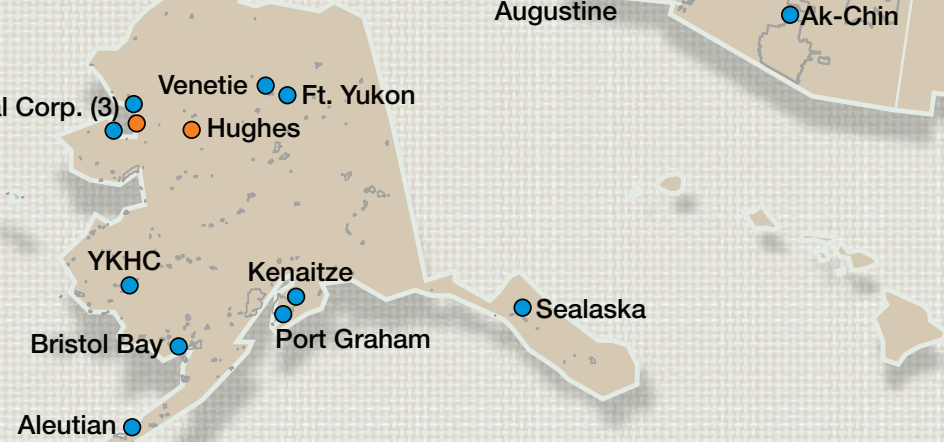

Tribes cost-shared \$4.1 million 


OO Peck (2) OTurtle Mountian

OFt. Berthold ORed Lake (2) White Earth 0 Lac du Flambeau O Sault Ste. Marie 2 Lac Courte Oreilles $O$ O Little Traverse $\begin{array}{ccc}O & O & O \\ \text { St. Croix } & \text { O Grand Traverse }\end{array}$ OLower Brule

ORosebud Winnebago (2)

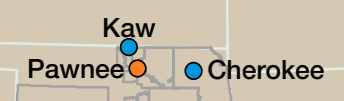
O Citizen Potawatomi (2) OFt. Sill Apache

Total of $88 \%$ of DOE funding directly to Tribes

OEastern Cherokee

๑Seneca (2)
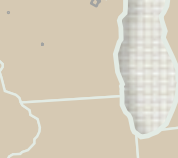

2 .
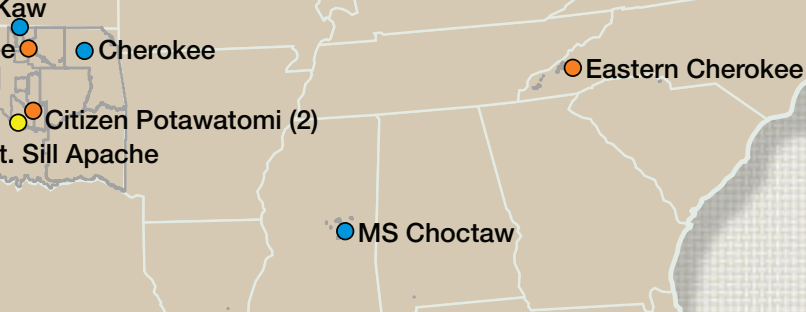

?)

\author{
Northern \\ Cheyenne Nation \\ wind resource \\ assessment
}

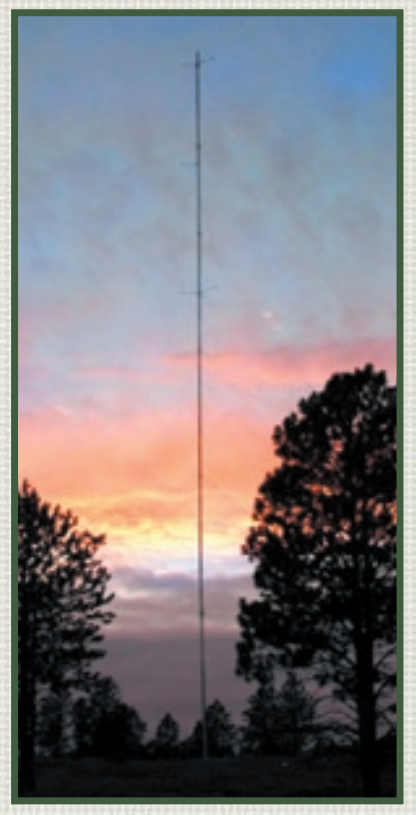

Penobscot 0

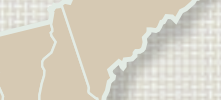

Solar electric array on Navajo home

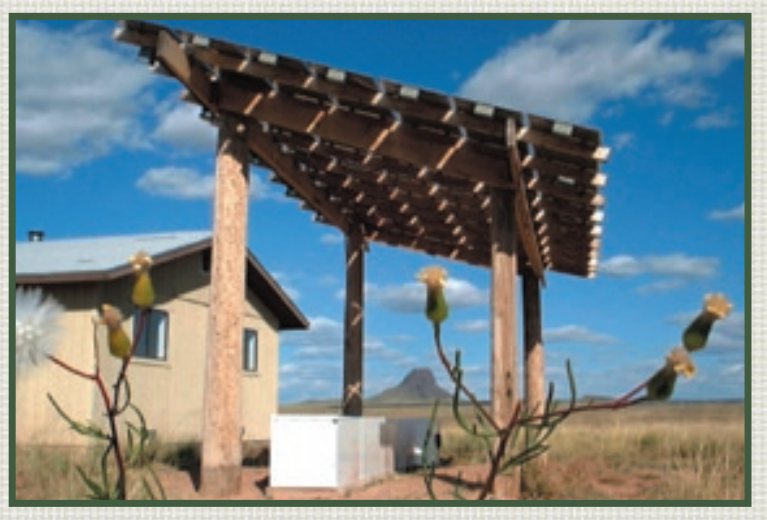




\section{U.S. Department of Energy}

\section{Energy Efficiency and Renewable Energy}

\section{Wind Energy}

Wind energy uses the energy in the wind for generating electricity, charging batteries, pumping water, or grinding grain. Large, modern wind turbines operate together in wind farms to produce electricity for utilities. Small turbines are used by homeowners and remote villages to help meet energy needs.

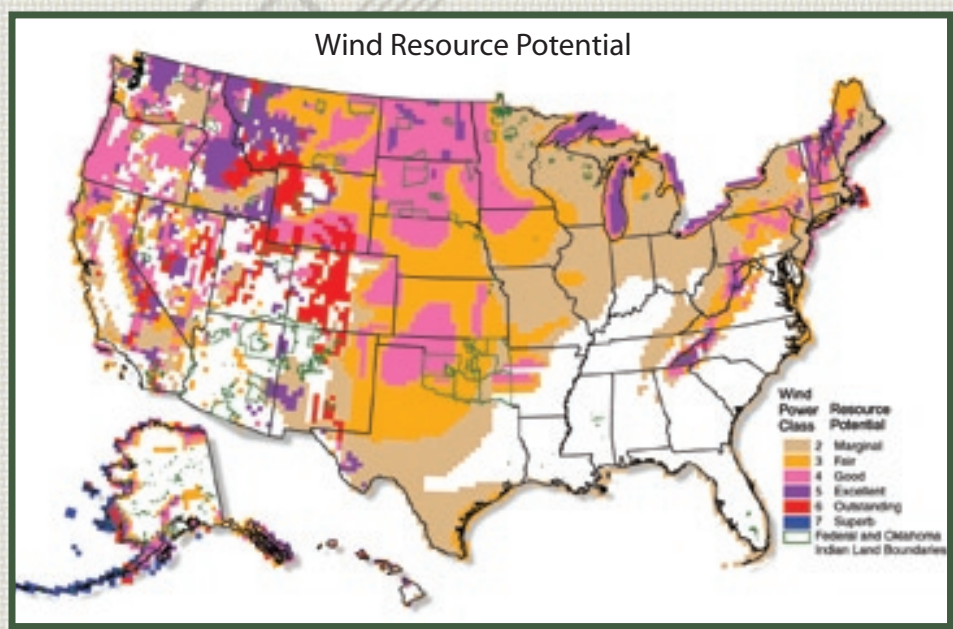

Areas designated class 4 or greater are suitable for most utilityscale wind turbine applications, whereas class 2 and 3 areas are marginal for utility-scale applications but may be suitable for remote applications.

\section{Solar Energy}

A square area in the Southwest 100 miles on each side could generate all the electricity used in the United States! Sunshine varies across the United States by about a factor of two, while utility rates vary by about a factor of 10 . Solar opportunities may exist in places you would not initially expect based only on resource assumptions.

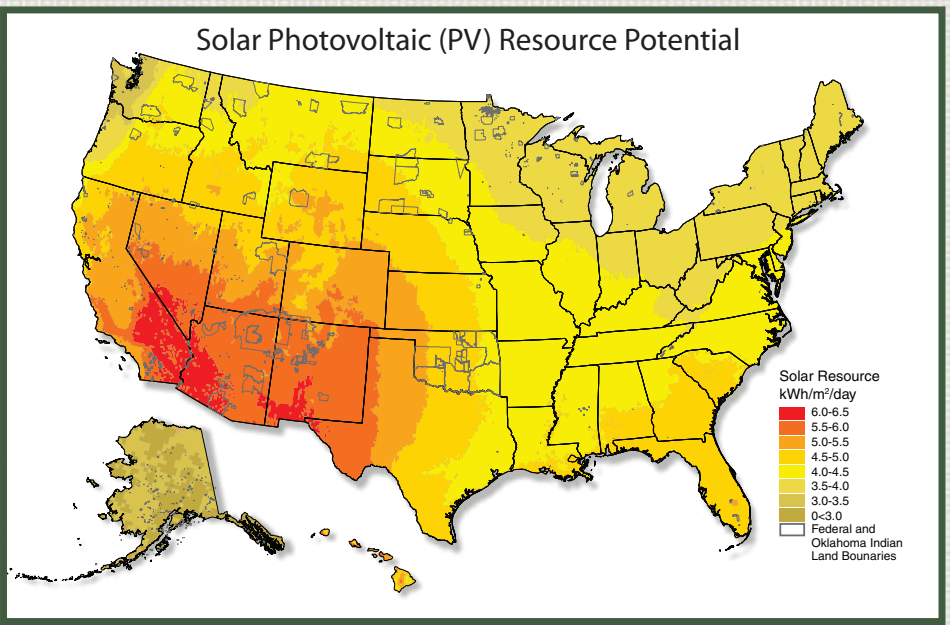

A distance from the nearest utility line of only a quarter mile raises distribution costs sufficiently to make PV cost-effective for small loads even in the cloudiest parts of the country.

\section{For resource information, visit DOE's}

Guide to Tribal Energy Development at www.eere.energy.gov/tribalenergy/guide 


\section{Biomass}

Biomass offers the opportunity to produce fuel, electric power, chemicals, and other industrial materials from renewable resources including agricultural crops and residues, trees and forest residues, grasses, animal wastes, and organic municipal solid wastes. Fuel products include ethanol, which can be produced from wood chips, rice straw, switchgrass, sugar cane waste, and corn; and renewable biodiesel, which can be produced from grain and grain products.

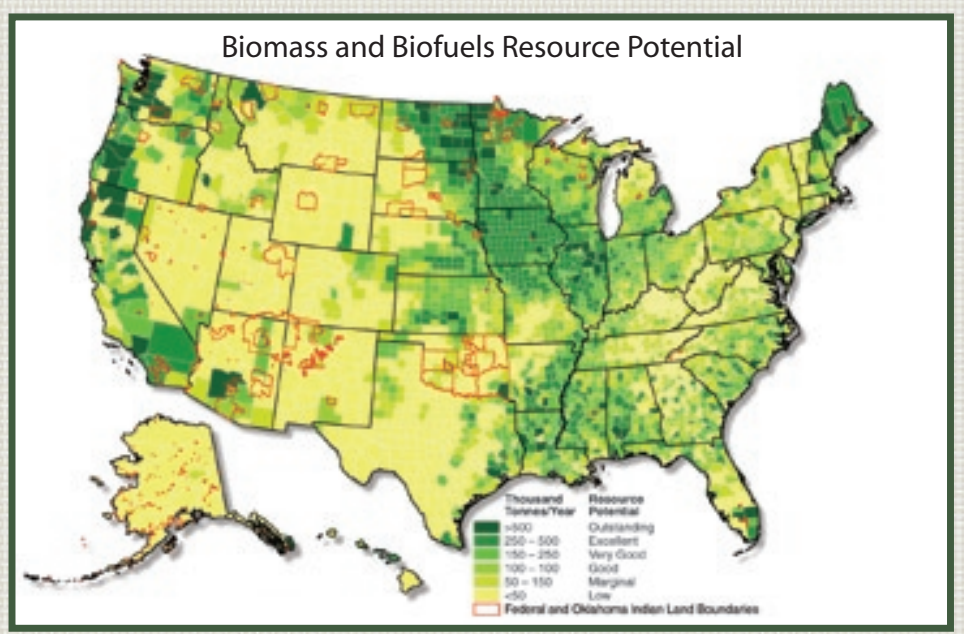

Today, various forms of biomass energy account for $45 \%$ of renewable energy used in the United States. Biomass resources must be assessed on a case-by-case basis. The most economic resources are often associated with residual materials from commercial or industrial processes.

\section{Hydropower}

Hydropower plants capture the kinetic energy of falling water to generate electricity, using a turbine and a generator to convert the energy from the water to mechanical and then electrical energy. Hydropower currently contributes the greatest share of renewable electricity generation in the United States. For more information, see http://hydropower.inel.gov/prospector/index.shtml

\section{Geothermal Energy}

Geo- (Earth) thermal (heat) energy is an enormous, underused heat and power resource that is clean, reliable, and homegrown (making us less dependent on fossil fuel). Earth's energy can be converted into heat and electricity. The three technology categories are geothermal heat pumps, direct-use applications, and electricity production.

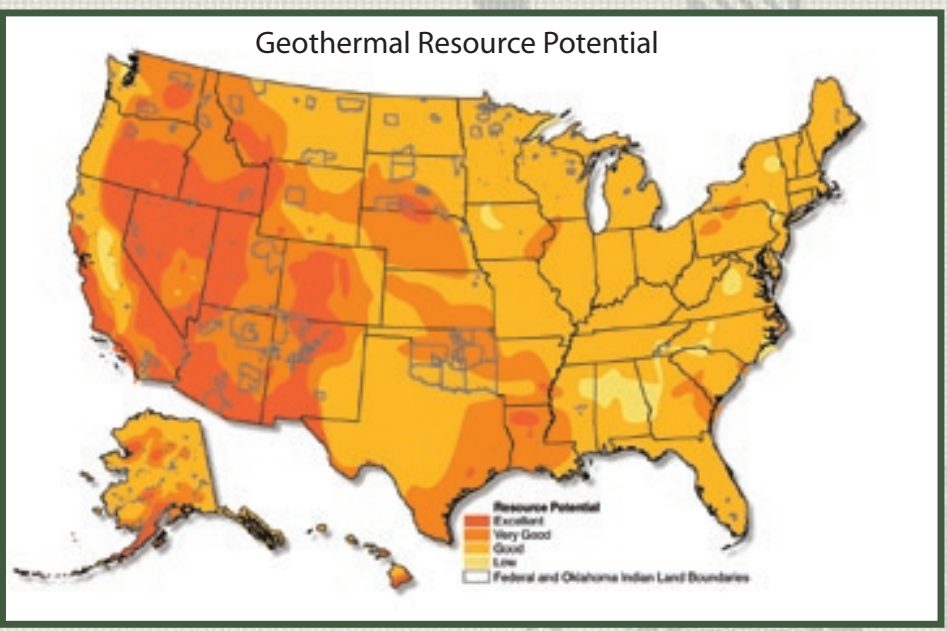

Geothermal (or ground source) heat pumps use temperatures found a few feet below the surface to transfer heat from the ground to the building in winter and from the building to the ground in summer. The rate of installation of ground-source heat pumps is thought to be between 10,000 and 40,000 per year. Direct-use geothermal resources can be used to heat buildings, melt snow, grow plants in greenhouses, dehydrate onions and garlic, heat water for fish farming, and pasteurize milk. Utility-scale electric power can be produced using deep wells, drilled into underground reservoirs to tap steam and very hot water to drive turbines and generators. 


\section{U.S. Department of Energy}

\section{Energy Efficiency and Renewable Energy}

\section{Funding Opportunities}

- Funding is provided on a competitive basis for the evaluation and development of renewable energy resources on Tribal lands.

- Each funding opportunity announcement will identify submission requirements, eligibility, and rating criteria.

\section{Tribal Wind Monitoring Sites}

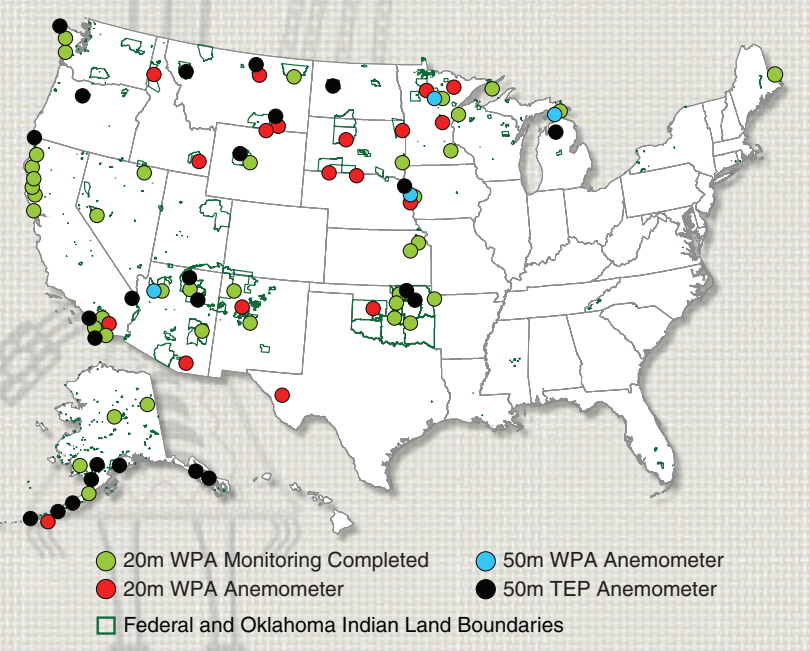

\section{Education and Training}

\section{- Student internships}

See the Web site for an application form

- Regional workshops

The Tribal Energy Program conducts periodic workshops for Tribes to learn about renewable energy and energy efficiency and how to develop those resources.

\section{- Renewable energy} short courses

Short courses have been conducted on biomass, solar, and wind energy; renewable energy analysis and economics; business development and project financing; and renewable energy for Tribal community development.

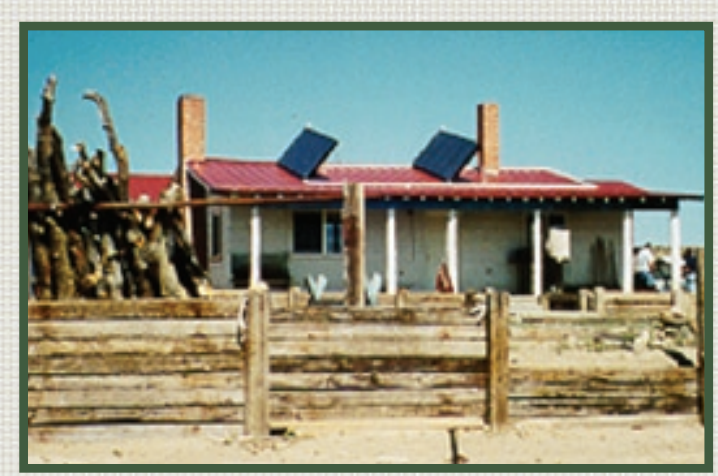

Solar installation at Pueblo of Laguna's Majors Ranch.

\section{Anemometer Loans}

- 20-meter and 50-meter anemometer towers are available to Tribes for wind resource monitoring

- To apply, see "Native Americans" at: www.eere.energy.gov/windandhydro/windpoweringamerica 


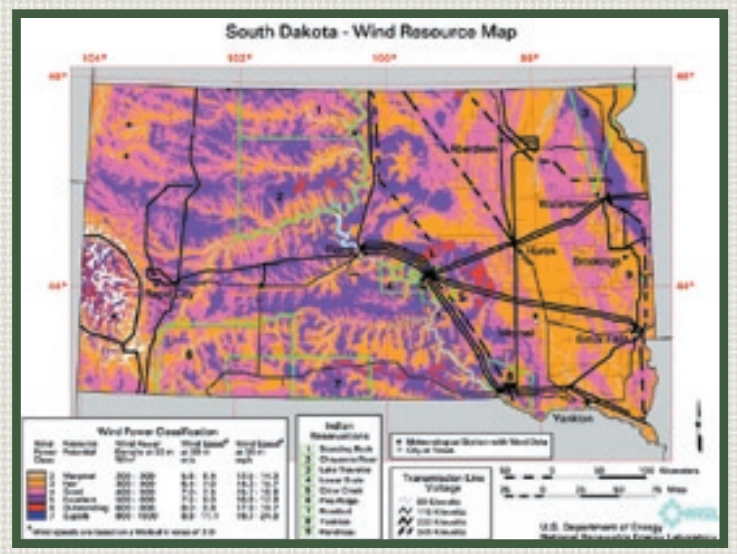

High-resolution wind prospecting maps are available for most Tribal regions.

\section{National Laboratory Technical Assistance}

- Strategic energy planning

- Renewable energy technology information

- Renewable resource information

- Project support

- Economic evaluations

- System performance models

- Policy information

- Design review

- Special studies

Assistance provided upon request within available resources. See Web site for instructions on submitting a request.

\section{Information}

- Tribal energy Web site www.eere.energy.gov/tribalenergy

- Features

- Program information

- Funding opportunities

- Project summaries

- Project contacts and reports

- Information resources

- Training opportunities

- Program contacts

\section{- Guide to Tribal energy development}

www.eere.energy.gov/tribalenergy/guide

- Development process

- Strategic planning

- Options analysis

- Organizational development

- Project development

- Resource library

- Energy resources

- Technologies

- Cost

- Risk factors

- Legal issues

- Financing options

- Contacts

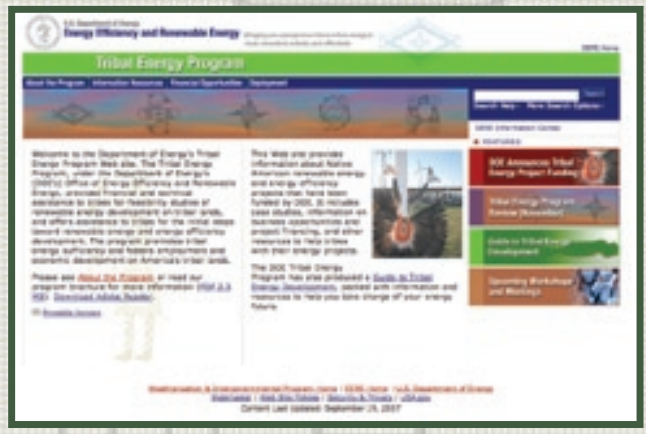

- Case studies

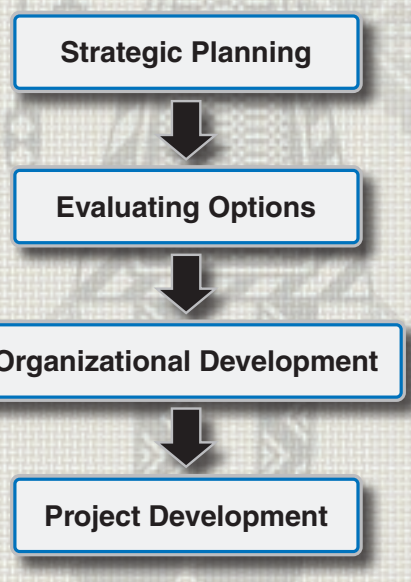




\section{U.S. Department of Energy}

\section{Energy Efficiency and Renewable Energy}

Thomas Sacco, Program Manager

Weatherization \& Intergovernmental Program Office of Energy Efficiency \& Renewable Energy U.S. Department of Energy, Washington, DC

\section{Tribal Energy Program Contacts}

The Tribal Energy Program consists of program management through DOE headquarters and program implementation through DOE's Golden Field Office. Technical support is provided through the DOE laboratories.

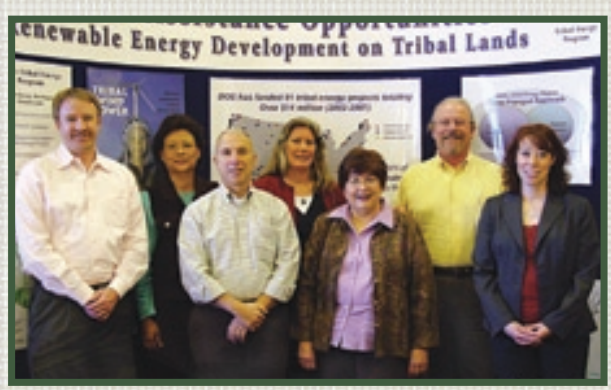

The Tribal Energy Program includes (from left to right) Scott Haase, Sandra Begay-Campbell, Thomas Sacco, Lizana Pierce, Victoria

DeHerrera, Roger Taylor, and Faline Haven.
Sandra Begay-Campbell

Sandia National Laboratories

Albuquerque, New Mexico

skbegay@sandia.gov

505-844-5418

\section{Roger Taylor}

National Renewable Energy Laboratory

Golden, Colorado

roger_taylor@nrel.gov

303-384-7389
Faline Haven

National Renewable Energy Laboratory Golden, Colorado

faline_haven@nrel.gov 303-384-7468

\section{Scott Haase}

National Renewable Energy Laboratory Golden, Colorado

scott_haase@nrel.gov 303-275-3057 
For more information on the Tribal Energy Program

visit our Web site at

\section{www.eere.energy.gov/tribalenergy}

To receive periodic information on funding opportunities, upcoming workshops and training, and other Tribal energy information, join our e-mail list by contacting

Lizana Pierce at lizana.pierce@go.doe.gov. 
Notice

This report was prepared as an account of work sponsored by an agency of the United States government. Neither the United States government nor any agency thereof, nor any of their employees, makes any warranty, express or implied, or assumes any legal liability or responsibility for the accuracy, completeness, or usefulness of any information, apparatus, product, or process disclosed, or represents that its use would not infringe privately owned rights. Reference herein to any specific commercial product, process, or service by trade name, trademark, manufacturer, or otherwise does not necessarily constitute or imply its endorsement, recommendation, or favoring by the United States government or any agency thereof. The views and opinions of authors expressed herein do not necessarily state or reflect those of the United States government or any agency thereof.
A Strong Energy Portfolio

for a Strong America

Energy efficiency and clean, renewable energy will mean a stronger economy, a cleaner environment, and greater energy independence for America. Working with a wide array of state, community, industry, and university partners, the U.S. Department of Energy's Office of Energy Efficiency and Renewable

Energy invests in a diverse portfolio of energy technologies.

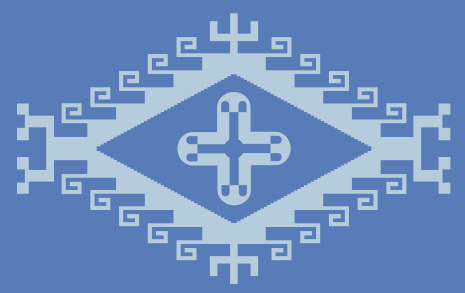

Produced for the

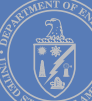

U.S. Department of Energy

Energy Efficiency and Renewable Energy

U.S. Department of Energy

1000 Independence Avenue S.W.

Washington, DC 20585

by the following DOE laboratories:

Sandia National Laboratories and

National Renewable Energy Laboratory

For more information contact:

EERE Information Center

1-877-EERE-INF (1-877-337-3463)

www.eere.energy.gov

DOE/GO-102007-2526

December 2007

Printed with renewable source ink on paper containing at Printed with renewable source ink on paper containing at
least $50 \%$ wastepaper, including $10 \%$ post consumer waste. 